\title{
Study of the demersal assemblages of the continental shelf and upper slope off Congo and Gabon, based on the trawl surveys of the RV 'Dr Fridtjof Nansen'
}

\author{
G. Bianchi \\ Institute of Marine Research, Division for International Development Programmes, PO Box 1870, Nordnes, N-5024 Bergen, Norway
}

\begin{abstract}
The structure of the demersal assemblages (fish, crustaceans and cephalopods) of the continental shelf and upper slope off Congo and Gabon (from about 1 to $5^{\circ} \mathrm{S}$ ) was studied based on the trawl survey of the RV 'Dr Fridtjof Nansen' in January-February 1989, by means of an ordination technique, Detrended Correspondence Analysis (DCA), implemented by the computer program DECORANA and a classification technique, Two-Way Indicator species Analysis (TWIA), implemented by the computer program TWINSPAN. Major faunal discontinuities were found between the shelf and the slope assemblages and, on the shelf, between the suprathermocline and the subthermocline assemblages. Correlation of DCA Axes 1 and 2 with the environmental variables showed in fact that temperature was most highly correlated with DCA Axis 1. The lack of any correlation with Axis 2 indicates that other factors (e.g. bottom type) also play an important role in explaining the various groups. Highest biomass densities (from bottom trawl catches) were found on the deeper shelf off Gabon and in the intermediate shelf off Congo.
\end{abstract}

\section{INTRODUCTION}

This study is one of a series aimed at describing the demersal assemblages of the areas surveyed by the RV 'Dr Fridtjof Nansen'. The main objective is to detect general trends in the distribution of bottom megafauna in relation to environmental variables. The groups included in the analysis are bony fishes, elasmobranchs, stomatopods, decapod crustaceans and cephalopods.

Several studies of the demersal communities on the continental shelf and upper slope off West Africa are available based on multivariate analysis techniques: Senegal-Gambia (Domain 1972); Mauritania (Domain 1980); Gulf of Guinea (Fager \& Longhurst 1968); Namibia (Lleonart \& Roel 1984, Mas-Riera et al. 1990); west coast of South Africa (Roel 1987); Angola (Bianchi 1992). Durand (1967) studied the biology of the benthic fishes of the continental shelf off Congo, and Fontana (1981) and Cayré \& Fontana (1981) described the coastal and the deep-sea demersal stocks off Congo, respectively.

\section{STUDY AREA}

Bottom topography and structure. The study area (Fig. 1) includes the shelf and upper slope off Gabon and Congo, from about 1 to $5^{\circ} \mathrm{S}$. The shelf slopes gently to about $100 \mathrm{~m}$ depth, but becomes steeper to $200 \mathrm{~m}$ depth so that $80 \%$ of the shelf area is shallower than $100 \mathrm{~m}$. The upper slope is very steep throughout, except off southern Congo. Information on bottom type was taken from navigation charts (Anon. 1976). The shelf off Gabon is dominated by sandy, sand-shell and gravel bottoms, but becomes muddy toward the shelf edge and the upper slope. Off Congo, while rocky areas and outcrops are found in the inshore part of the shelf, its intermediate and deeper parts are dominated by muddy, mud-sand bottoms. This might be due to the transport by currents of sediments from the Congo River Estuary.

Hydrography and biological oceanography. Wauthy (1983) has described the general oceanography of the Gulf of Guinea while the survey report by Sætersdal 


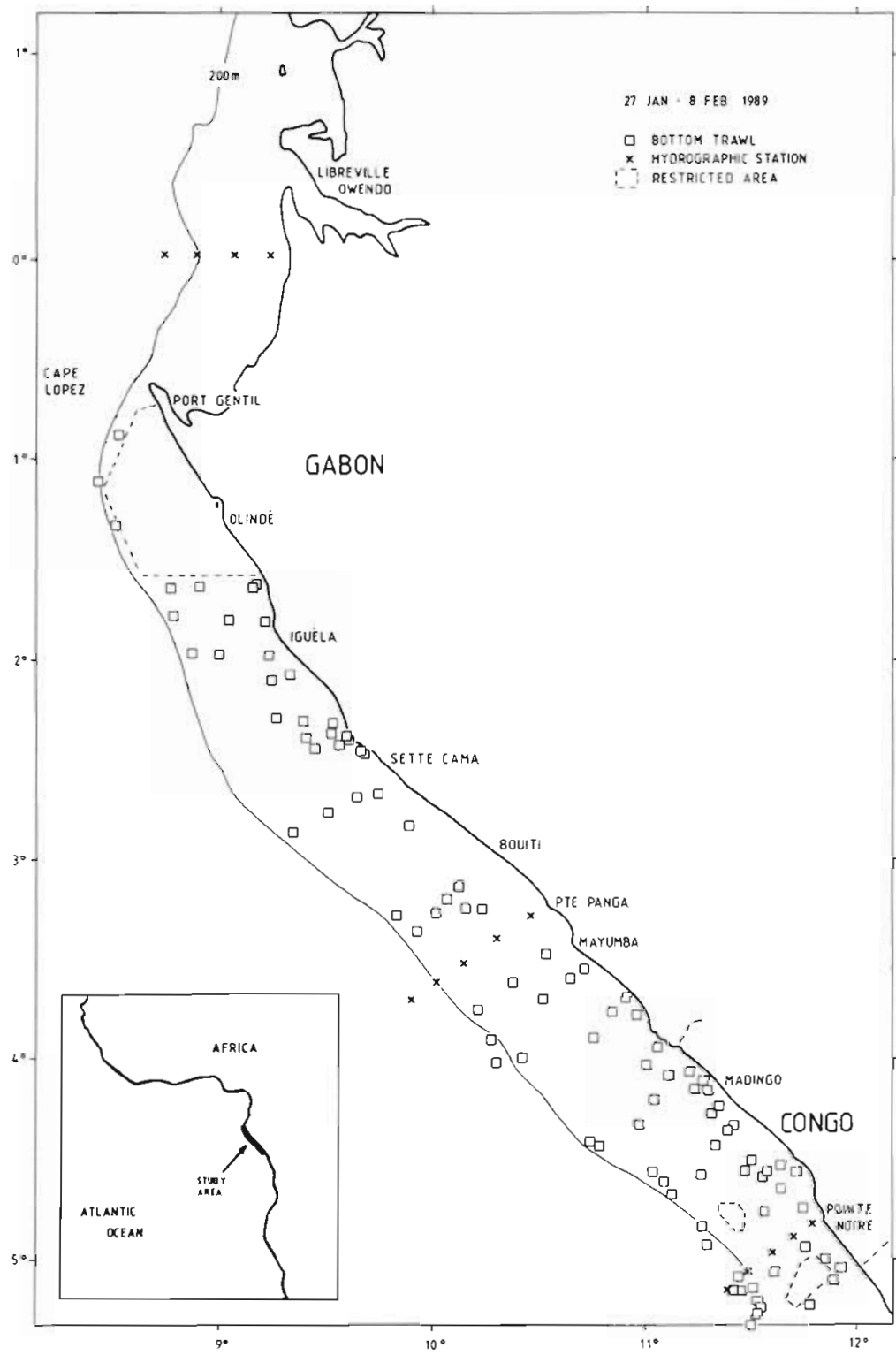

Fig. 1. Position of trawl hauls and hydrographic stations. January-February 1989

(1989) gives a description of the oceanographic conditions in the area at the time of the survey. The productive systems of the eastern tropical Atlantic between $20^{\circ} \mathrm{N}$ and $15^{\circ} \mathrm{S}$ were described and compared by Voituriez \& Herbland (1982).

The circulation pattern in this area varies seasonally and can be related to the general circulation pattern of the Equatorial Atlantic Ocean, i.e. the westward flowing South Equatorial Current (SEC), forming the northern part of the south Atlantic gyre, and the eastward flowing subsurface South Equatorial Counter Current (SECC). The former originates between about Cape Lopez (Gabon) and $15^{\circ} \mathrm{S}$ (Angola). During the austral summer (January-February) there is a general movement in a northwesterly direction (Wauthy 1983) and low-salinity waters originating from the Congo River can be traced as far north as Cape Lopez. In this period, because of the intensive solar radiation, surface waters reach high temperatures $\left(28\right.$ to $30^{\circ} \mathrm{C}$ ) and a shallow and sharp thermocline is found at about 20 to $30 \mathrm{~m}$ depth in the north, becoming deeper (between 25 and $50 \mathrm{~m}$ ) southward (Sxetersdal 1989). Temperatures of 20 and $18^{\circ} \mathrm{C}$ are found at about $50 \mathrm{~m}$ and at the shelf edge, respectively. The halocline is also very sharp, mainly because of the increased rainfall and the increased runoff from the Congo River (Fig. 2). During the austral winter, the main water movement is westward, because of the reinforcement of the South East Trade Winds. Surface temperatures are 3 to $5^{\circ} \mathrm{C}$ lower and the thermocline not as sharp. Low-salinity surface waters are now only found in the south (from the Congo River) and in the north (off northern Gabon) originating from the Gulf of Biafra. The raising of the thermocline, cooling of the surface waters and increase of primary production have been interpreted as signs of upwelling. Relatively high oxygen levels $\left(\mathrm{O}_{2}>2.5 \mathrm{ml} \mathrm{l}^{-1}\right)$ are found throughout the shelf, all year round (Anon. 1986).

Factors contributing to the enrichment in nutrients are related to seasonal upwelling, the discharge from the Congo River and shelf-break upwelling (Longhurst \& Pauly 1987). Voituriez \& Herbland (1982) argue that the seasonal upwelling of this region does not seem to be wind-induced and that there is no real strong vertical transport. This upwelling might be due to increased wind strength in the western Atlantic and production of a Kelvin wave along the Equator in a west-east direction. It should be emphasized that the seasonal upwelling in this area, although responsible for higher primary production, does not entail the dramatic changes typical of stable upwelling systems, as for example oxygen depletion on the shelf bottom and clear uptilting of the thermocline. According to Voituriez \& Herbland (1982), 'upwelling' should not be used for these systems unless its meaning is expanded to all situations where the upper nitratedepleted layer does not exist independently from the mechanism of enrichment. 


\section{MATERIAL AND METHODS}

Trawl data. Material was collected in 1989, during the summer season (28 January to 8 February). A shrimp and fish trawl was used, with headline of $31 \mathrm{~m}$, footrope of $47 \mathrm{~m}$ and estimated headline height and distance between wings during towing of 6 and 18 to $20 \mathrm{~m}$ respectively. Stretched mesh size was $2 \mathrm{~cm}$, with double lining in the cod end. Each tow had a standard duration of $30 \mathrm{~min}$. Other details on the gear used can be found in Satersdal (1989). Bottom trawl stations were randomly set along the cruise track. A total of 96 stations were sampled in the course of the above survey (Fig. 1). Of these, 2 stations considered as 'non-valid' (because of gear damage) were not included in the analysis.

Each species caught was identified, counted and weighed separately. Fischer et al. (1981) and Bianchi (1986) were used for identifying the species in the catches. Congeneric species which were difficult to separate were pooled together. All station and species data were stored using the B-trieve file system (data available in ASCII format upon request).

Hydrographic data. Samples for temperature, salinity and oxygen were taken using Nansen bottles at standard depths and along fixed transects (Fig. 1). In the present analysis, the values of these variables at each station were inferred from the nearest hydrographic station.

Data analysis. The analysis was performed with the help of multivariate analytical techniques, i.e. the classification method Two-Way Indicator species Analysis (TWIA; Hill 1979), implemented by the program TWINSPAN, and an ordination method, Detrended Correspondence Analysis (DCA; Hill \& Gauch 1980), implemented by the program DECORANA. The former is a divisive method that classifies sites and species and produces a sorted species by station table, showing the hierarchical classification in binary notation. Indicator species are also part of the output from this method. These are species showing clear ecological preferences and are used to identify particular environmental conditions. DCA produces an ordination of the stations based on the abundance values of the species. The ordination summarizes multivariate
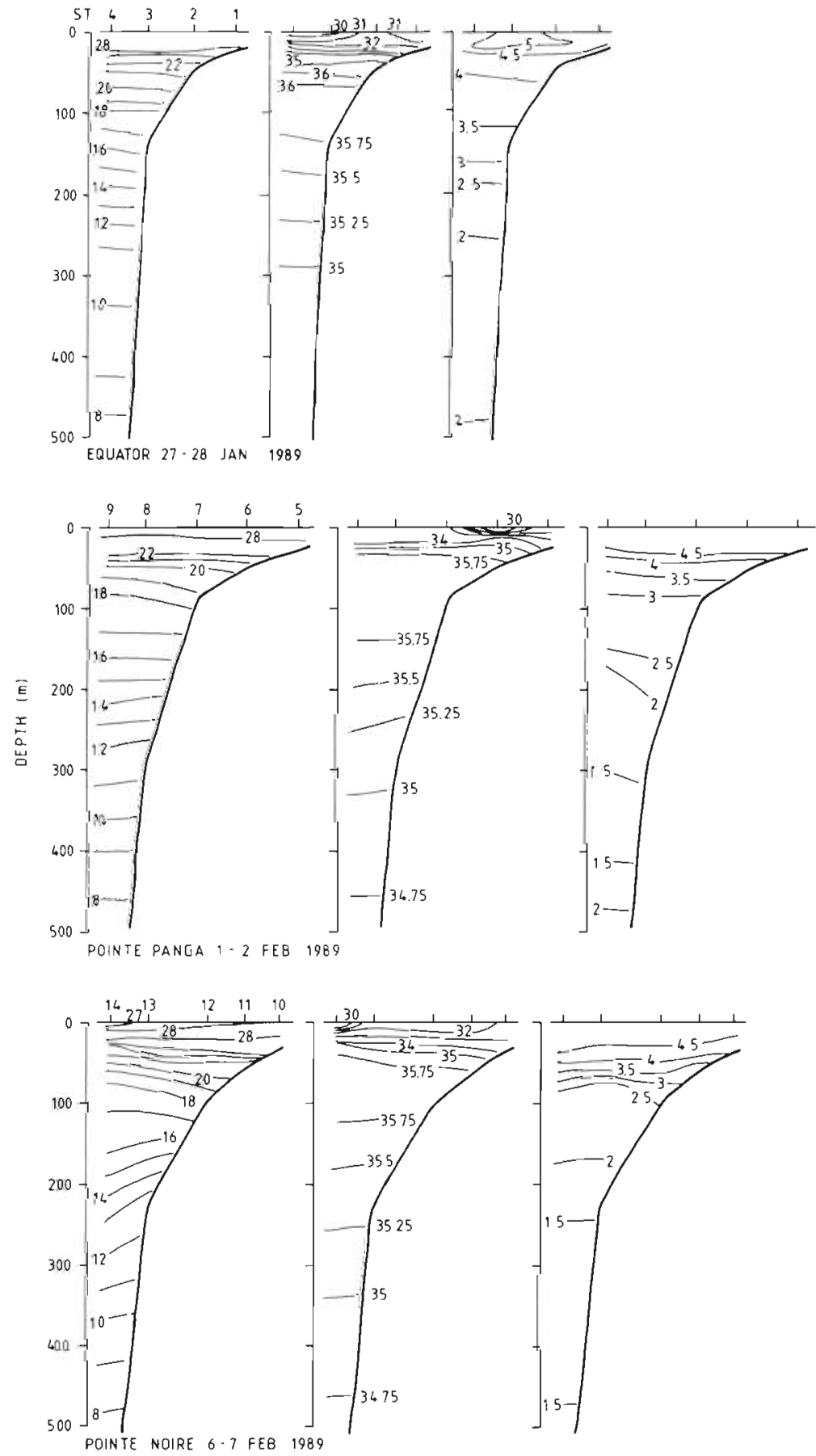

Fig. 2. Hydrographic profiles for temperature, salinity and oxygen at selected places along the Congo and Gabon coasts (see also Fig. 1). January-February 1989

data in a scatter, low-dimensional diagram and it is also useful for detecting possible outliers. The use of methods based on Correspondence Analysis has proven particularly useful in ecological studies, mainly because the underlying ecological model is unimodal (Jongman et al. 1987). The use of DCA has been criti- 
cized (Jackson \& Somers 1991) because of the instability of the results when varying the number of segments. However, this seems to be true when the number of samples is small as compared to the chosen number of segments and for short gradients. In the case of long gradients this effect is smaller and, conversely, the arch effect and compression of the extremes become stronger when using $C A$ without detrending. Therefore, it was still found more appropriate to use DCA in this study. In addition, the DCA version used correlates the main gradients (axes) with given environmental variables (ter Braak 1987). As a result of the analysis, average values and $\mathrm{SD}$ of the environmental variables are also produced for each group identified.

In this study biomass (wet wt) was used as a measure of abundance. Biomass seems to be ecologically appropriate and can be more relevant for practical applications as for example in fishery management.

Each weight, $x$, was converted to $\ln (x+1)$ before analysis with DCA. This transformation minimizes the dominant effect of anomalous catches. The addition of 1 unit is necessary to avoid problems derived by the presence of values $=0$ or values $<1$. No transformation is necessary in the case of TWIA, where abundances are converted to numbers corresponding to different abundance classes ('pseudospecies'). In this study 5 pseudospecies were used, corresponding to classes with lower limits set at $0,0.5,5,50$ and $500 \mathrm{~kg}$.
Demersal biomass densities (weight per unit area) were calculated using the 'swept-area' method by depth stratum:

$$
D_{\mathrm{j}}=C_{\mathrm{j}} / q \mathrm{a}_{\mathrm{j}}
$$

where $D_{\mathrm{j}}=$ density in Stratum $j\left[\mathrm{t}(\mathrm{n} \text { mile })^{-2}\right] ; C_{\mathrm{j}}=$ catch taken in hauls in Stratum $j(t) ; a_{j}=$ surface of the bottom 'swept' by the trawl hauls in Stratum $j$ (n mile) $)^{-2} ; q=$ catchability coefficient $(=1$, i.e. all fish in the path of the trawl were caught). This is a standard assumption in the surveys of the RV 'Dr Fridtjof Nansen' because, in the lack of studies on bottom trawl selectivity for tropical fishes, this choice yields the most conservative results (the lowest biomass estimates).

In the swept-area analysis, shallow-water pelagic species caught in the bottom trawl were not excluded. It is indeed quite difficult to differentiate between pelagic and demersal for the shallow-water species. Small pelagic fish of this depth zone are often found quite close to the bottom; some of them feed on bottom detritus and are preyed upon by both demersal and pelagic predators.

\section{RESULTS}

A total of 354 species comprising 1050018 specimens (31 $161 \mathrm{~kg}$ ) were sampled in January-February 1989. Table 1 gives the list of the most important species collected and used in the analysis.

Table 1. Main species collected in 1989 off Congo-Gabon, by major taxonomic groups and families

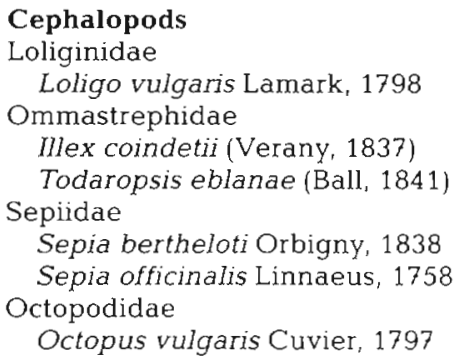

\section{Decapod crustaceans}

Solenoceridae

Solenocera africana Stebbing, 1917

Aristeidae

Aristeus varidens Holthuis, 1952

Aristeus antennatus Risso

Penaeidae

Parapenaeopsis atlantica Balss, 1914

Parapenaeus longirostris (Lucas, 1846)

Penaeus notialis Pérez-Farfante, 1967

Penaeus kerathurus (Forsskål, 1814)

Nematocarcinidae

Nematocarcinus africanus Crosnier \& Forest, 1973

Portunidae

Portunus validus (Herklots, 1851)
Polychaelidae

Palinuridae

Panulirus regius De Brito Capello, 1864

Sharks

Squalidae

Centrophorus uyato (Rafinesque, 1809)

Etmopterus spp

Squatinidae

Squatina oculata Bonaparte, 1840

Triakidae

Mustelus mustelus (Linnaeus, 1758)

Carcharhinidae

Rhizoprionodon acutus (Rüppel, 1937)

Sphyrnidae

Sphyrna lewini (Cuvier, Griffith \& Smith, 1834)

Batoid fishes

Rhinobatidae

Rhinobatos albomaculatus Norman, 1930

Rajidae

Raja miraletus Linnaeus, 1758

Torpedinidae

Torpedo marmorata Risso, 1810

Dasyatidae

Dasyatis margarita (Günther, 1870) 
Table 1 (continued)

\begin{tabular}{|c|c|}
\hline Bony fishes & Lutjanidae \\
\hline Albulidae & Lutjanus fulgens (Valenciennes, 1830) \\
\hline Pterothrissus belloci Cadenat, 1937 & Lutjanus dentatus (Dumeril, 1858) \\
\hline Clupeidae & Haemulidae \\
\hline Ilisha africana (Bloch, 1795) & Brachydeuterus auritus (Valenciennes, 1831) \\
\hline Sardinella aurita Valenciennes, 1847 & Plectorhynchus mediterraneus (Guichenot, 1850) \\
\hline Sardinella maderensis (Lowe, 1839) & Pomadasys incisus (Bowdich, 1825) \\
\hline Gonostomatidae & Pomadasys jubelini (Cuvier, 1830) \\
\hline $\begin{array}{l}\text { Yarrella blackfordi Goode \& Bean, } 1896 \\
\text { Ariidae }\end{array}$ & $\begin{array}{l}\text { Pomadasys peroteti (Cuvier, 1830) } \\
\text { Lethrinidae }\end{array}$ \\
\hline $\begin{array}{l}\text { Ariidae } \\
\text { Arius heudeloti Valenciennes, } 1840\end{array}$ & $\begin{array}{l}\text { Lethrinidae } \\
\text { Lethrinus atlanticus Valenciennes, } 1830\end{array}$ \\
\hline $\begin{array}{l}\text { Arius heudeloti Valenciennes, } 1840 \\
\text { Arius latiscutatus (Günther, 1894) }\end{array}$ & $\begin{array}{l}\text { Letnrinus atlanticus valenciennes, } 1830 \\
\text { Sparidae }\end{array}$ \\
\hline $\begin{array}{l}\text { Arius latiscutatus (Günther, 1894) } \\
\text { Arius parkii Günther, } 1864\end{array}$ & Boops boops (Linnaeus, 1758) \\
\hline $\begin{array}{l}\text { Anus parkn Gunther, } 1864 \\
\text { Myctophidae }\end{array}$ & Dentex angolensis Poll \& Maul, 1953 \\
\hline $\begin{array}{l}\text { Myctophidae } \\
\text { Synodontidae }\end{array}$ & Dentex barnardi (Cadenat, 1970) \\
\hline Saurida brasiliensis Norman, 1935 & Dentex canariensis Steindachner, 1881 \\
\hline Trachinocephalus myops (Forster, 1801) & Dentex congoensis Poll, 1954 \\
\hline Ogcocephalidae & $\begin{array}{l}\text { Dentex gibbosus (Rafinesque, } 1810 \text { ) } \\
\text { Pagellus bellottii Steindachner, } 1882\end{array}$ \\
\hline Dibranchus atlanticus Peters, 1875 & Sparus auriga (Valenciennes, 1843) \\
\hline Ophidiidae & Sparus caeruleostictus (Valenciennes, 1830) \\
\hline Brotula barbata (Bloch) in Bloch \& Schneider, 1801 & Sparus pagrus africanus (Akazaki, 1962) \\
\hline Merlucciidae & Sciaenidae \\
\hline Merluccius polli Cadenat, 1950 & Pentheroscion mbizi (Poll, 1950) \\
\hline Moridae & Pseudotolithus senegalensis (Valenciennes, 1833) \\
\hline Physiculus spp. & Pseudotolithus typus Bleeker, 1863 \\
\hline Macrouridae & Pteroscion peli (Bleeker, 1863) \\
\hline Coelorinchus coelorhincus (Risso, 1810) & Umbrina canariensis Valenciennes, 1843 \\
\hline Malacocephalus laevis (Lowe, 1843) & Mullidae \\
\hline Malacocephalus occidentalis Goode \& Bean, 1885 & $\begin{array}{l}\text { Pseudupeneus prayensis (Cuvier, 1829) } \\
\text { Sphyraenidae }\end{array}$ \\
\hline $\begin{array}{l}\text { Trachichthyidae } \\
\text { Hoplostethus cadenati Quero, } 1974\end{array}$ & $\begin{array}{l}\text { Sphyraenidae } \\
\quad \text { Sphyraena guachancho Cuvier, } 1829\end{array}$ \\
\hline Zeidae & Polynemidae \\
\hline Zenopsis conchifer (Lowe, 1852) & Galeoides decadactylus (Bloch, 1795) \\
\hline Fistulariidae & Pentanemus quinquarius (Linnaeus, 1758) \\
\hline Fistularia petimba (Lacepède, 1803) & $\begin{array}{l}\text { Uranoscopidae } \\
\text { Uranoscopus albesca Regan, } 1915\end{array}$ \\
\hline Percophidae & Trachinidae \\
\hline Bembrops heterurus (Miranda Ribeiro, 1915) & Trachinus armatus (Bleeker, 1862) \\
\hline Platycephalidae & Trachinus radiatus Cuvier, 1829 \\
\hline Grammoplites gruveli (Pellegrin, 1905) & Acanthuridae \\
\hline Scorpaenidae & Acanthurus monroviae Steindachner, 1866 \\
\hline Neomerinthe folgori (Postel \& Roux, 1964) & Scombridae \\
\hline Pontinus spp. & Scomberomorus tritor (Cuvier, 1831) \\
\hline Triglidae & Trichiuridae \\
\hline Chelidonichthys gabonensis (Poll \& Roux, 1955) & Benthodesmus tenuis (Günther, 1877) \\
\hline Lepidotrigla cadmani Regan, 1915 & $\begin{array}{l}\text { Trichiurus lepturus Linnaeus, } 1758 \\
\text { Stromateidae }\end{array}$ \\
\hline $\begin{array}{l}\text { Lepidotrigla carolae Richards, } 1968 \\
\text { Dactylonteridae }\end{array}$ & $\begin{array}{l}\text { Stromateidae } \\
\text { Stromateus fiatola Linnaeus, } 1758\end{array}$ \\
\hline $\begin{array}{l}\text { Dactylopteridae } \\
\text { Dactylopterus volitans (Linnaeus, 1758) }\end{array}$ & Ariommidae \\
\hline Peristediidae & Ariomma bondi Fowler, 1930 \\
\hline Peristedion cataphractum Linnaeus, 1758 & Citharidae \\
\hline Serranidae & Citharus linguatula (Linnaeus, 1758) \\
\hline Epinephelus aeneus (Geoffroy Saint-Hilaire, 1809) & Psettodidae \\
\hline Priacanthidae & Psettodes erumei Bennet, 1831 \\
\hline Priacanthus arenatus Cuvier, in Cuv. \& Val., 1829) & Bothidae \\
\hline Acropomatidae & $\begin{array}{l}\text { Bothus podas (Delaroche, 1809) } \\
\text { Syacium micrurum (Ranzani, 1849) }\end{array}$ \\
\hline Synagrops microlepis Norman, 1935 & Soleidae \\
\hline Carangidae & Dicologoglossa cuneata (De la Pylaie Moreau, 1881) \\
\hline Chloroscombrus chrysurus (Linnaeus, 1766) & Cynoglossidae \\
\hline Decapterus punctatus (Cuvier, 1829) & Cynoglossus browni Chabanaud, 1949 \\
\hline Selene dorsalis (Gill, 1862) & Cynoglossus canariensis Steindachner, 1882 \\
\hline Trachurus trecae Cadenat, 1949 & Tetraodontidae \\
\hline Centracanthidae & Lagocephalus laevigatus (Linnaeus, 1766) \\
\hline Spicara alta (Osorio, 1917) & Balistidae \\
\hline Gerreidae & Balistes capriscus Gmelin, 1788 \\
\hline Eucinostomus melanopterus (Bleeker, 1863) & Balistes punctatus Gmelin, 1788 \\
\hline
\end{tabular}


Appendix 1 shows the results from TWIA. The first division separates the deep-water, slope groups (7,8 \& 9) from the shelf groups ( 1 to 6 ). At the second division level the shallow water assemblages (Groups 1 \& 2) separate from the assemblages of the deeper shelf (Groups 3 to 6), while Group 7 separates from the 2 deeper slope assemblages. At the third division level further separation into groups is not related to depth stratification. Fig. 3 shows the plot of stations on the first 2 DCA axes. The eigenvalues of the first 4 axes were $0.91,0.47,0.38$ and 0.28 respectively, which shows that the gradient represented by the first axis is by far the most important. Table 2 shows the correlation of these with the environmental variables and with latitude. Depth, temperature and oxygen are strongly correlated with DCA Axis $1(r=0.92,-0.98$ and -0.93 respectively) and significantly correlated with salinity. Axis 2 is not significantly correlated with any of the above variables.

Fig. 4 shows station positions after being assigned to each group. The average values of the measured environmental variables are presented in Table 3 while Table 4 provides, by station groups and for the most important species, total weight and numbers.

\section{Shallow water and coastal assemblages}

Group 1 - shallow water assemblage (off Gabon). The 6 stations included in this group have an average depth of $11 \mathrm{~m}$, temperature $28^{\circ} \mathrm{C}$, high oxygen concentrations (4.8 $\mathrm{ml} \mathrm{l}^{-1}$, on average) and low salinity $(32 \%)$. They were sampled off Gabon, north of Sette Cama (Fig. 4). The indicator species is the spiny turbot Psettodes belcheri that was caught at all stations of this group (Appendix 1). This species is known to occur on sandy and rocky bottoms. Other common species were the bluespotted seabream Sparus caeruleostictus, African threadfin Galeoides decadactylus, the tonguesole Cynoglossus browni, the spiny lobster Panulirus regius, the stingray Dasyatis margarita, and the bumper Brachydeuterus auritus. A number of pelagic species usually associated with the above demersal fauna were the West African ilisha llisha africana, the Atlantic bumper Chloroscombrus chrysurus, and the guachanche barracuda Sphyraena guachancho. No species was dominating in biomass and some species are known to occur in deeper waters. The juveniles of several species were found here (Satersdal 1989), i.e. the bumper, threadfin, barracuda and other nonidentified species, indicating that the area where the stations of this group were sampled is a nursery area.

Group 2 - shallow water assemblage (mainly off Congo). Twenty-six stations, mainly off Congo and southern Gabon, are included in this group, at an average depth of $21 \mathrm{~m}$, high temperature and oxygen concentrations $\left(27.1^{\circ} \mathrm{C}\right.$ and $4.6 \mathrm{ml} \mathrm{l}^{-1}$, respectively). Brachydeuterus auritus dominated both in biomass and numbers (Table 4) while typical demersal species

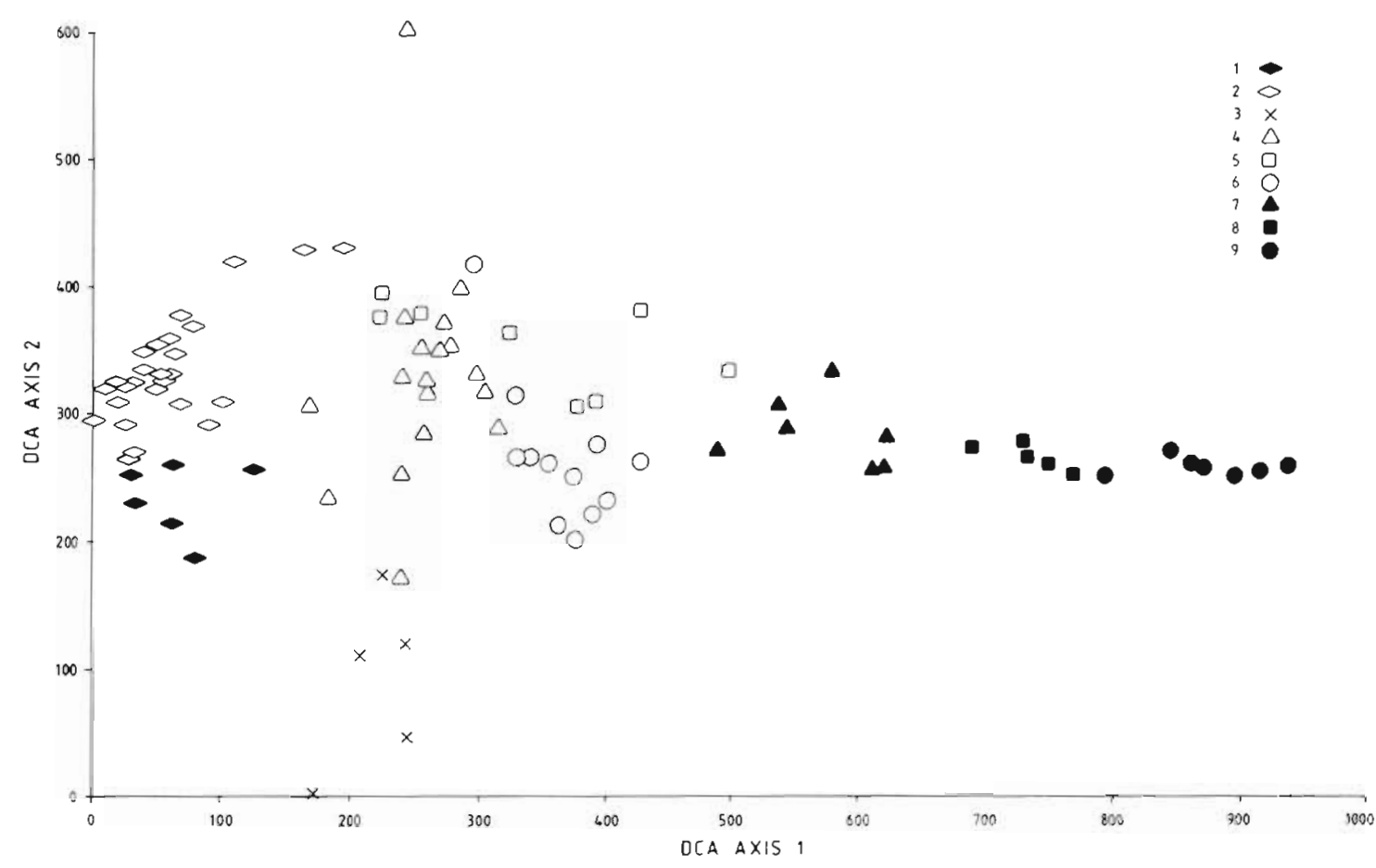

Fig. 3. Detrended correspondence analysis of bottom-trawl stations in the January-February survey 1989 (SD units $\times 100$ ). Corresponding TWIA (Two-Way Indicator species Analysis) Groups 1 to 9 can be recognized by the different symbols 
Table 2. Pearson product-moment correlation coefficient between sample scores on DCA (Detrended Correspondence Analysis) Axes 1 and 2 and environmental variables for all stations

\begin{tabular}{|lrr|}
\hline Variable & Axis 1 & Axis 2 \\
\hline Depth & $0.92^{\circ}$ & -0.12 \\
Temperature & $-0.98^{\circ}$ & 0.11 \\
Salinity & $0.55^{\circ}$ & -0.00 \\
Oxygen & $-0.93^{\circ}$ & 0.05 \\
& & \\
'Significant correlation, $\mathrm{p}<0.05, \mathrm{df}=91$ & \\
\hline
\end{tabular}

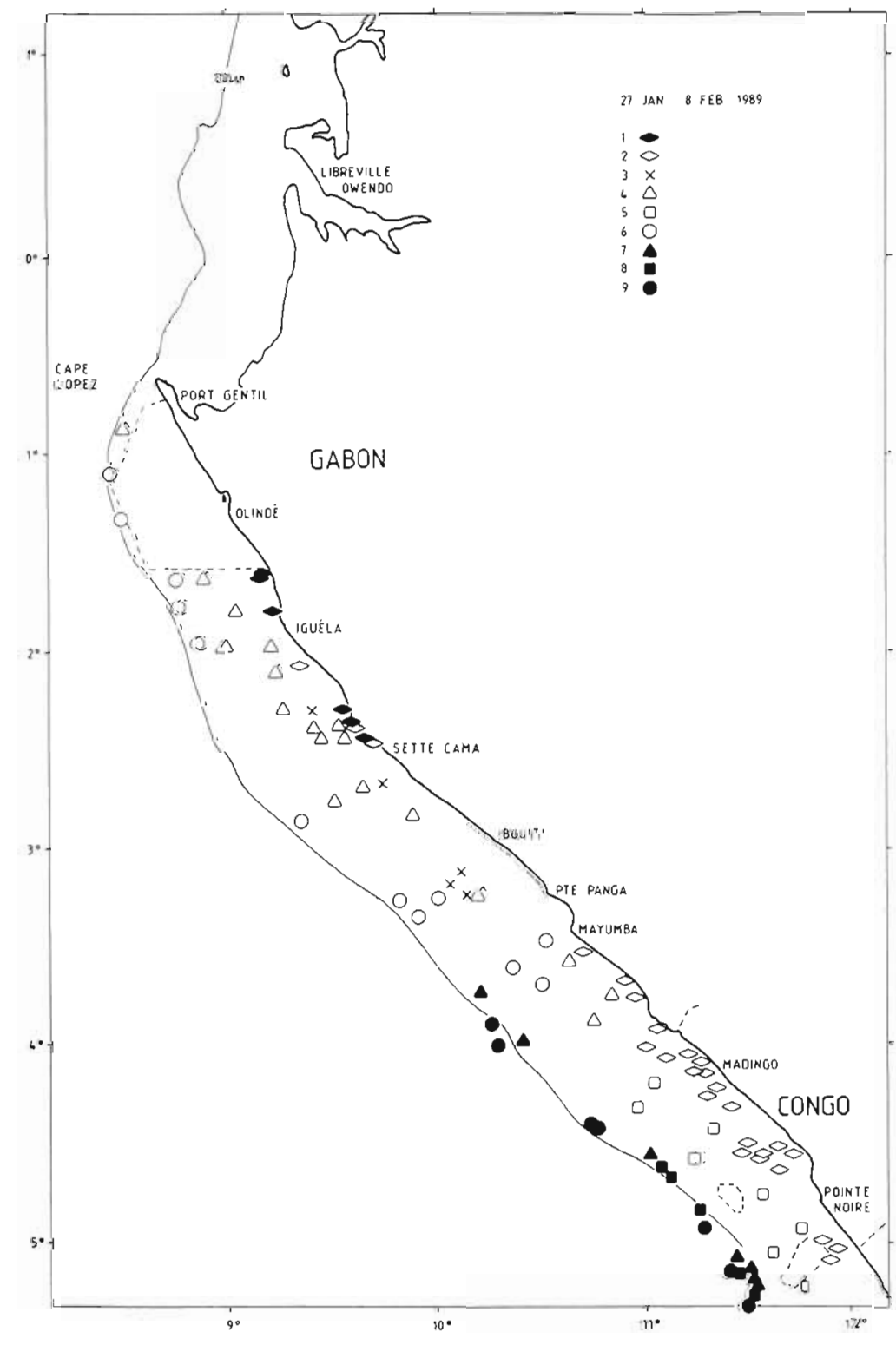

Fig. 4. Station positions after being assigned to the different groups of this group were the croakers Pseudotolithus senegalensis and P. typus, the threadfins Galeoides decadactylus and Pentanemus quinquarius. A number of benthopelagic and pelagic species were caught in association with these: Chloroscombrus chrysurus, Ilisha africana, the drum Pteroscion peli, the African lookdown Selene dorsalis and typical fish predators such as the hairtail Trichiurus lepturus and Sphyraena guachancho. This corresponds to the shallow water assemblage also described by Durand (1967) for Congo and by Domain (1980) for the continental shelf off Senegal and Mauritania, as well as to the 'estuarine and offshore sciaenid subcommunities' of the Gulf of Guinea described by Longhurst (1965) and Fager \& Longhurst (1968). This assemblage also typifies the shallow waters of northern and central Angola (Bianchi 1992).

Group 3 - coastal assemblages, just below the thermocline, on sandy/hard bottoms. This is a group of 5 stations with an average depth of ca $39 \mathrm{~m}$, temperature of $22^{\circ} \mathrm{C}$, oxygen concentration of $4 \mathrm{ml} \mathrm{l}^{-1}$ and salinity $35.2 \%$, between Pointe Panga and Sette Cama. The golden African snapper Lutjanus fulgens, the grunt Plectorhynchus mediterraneus, Sparus caeruleostictus, the white grouper Epinephelus aeneus, the Canary dentex Dentex canariensis and the seabream Sparus auriga made up $75 \%$ of the catches of Group 3 while all species of Groups 1 and 2 were either present in small quantities or absent, probably because of the markedly lower temperature. Navigation charts (Anon. 1976) report mainly sand, shingle and gravel in this area and this fits with the substratum preferences of the above species as reported in the literature (Fischer et al. 1981). Also, Brachydeuterus auritus and Trichiurus lepturus, species with a preference for soft bottoms, were completely absent.

Group 4 - coastal assemblage, just below the thermocline, on sandy bottoms. This group is almost identical to Group 3 in its values for environmental variables (Table 3 ) and largely overlaps in geographical location (Fig. 4). A number of species were common to both groups: the goatfish Pseudupeneus prayensis, the cornetfish Fistularia petimba, the weever Trachinus armatus, the cuttlefish Sepia officinalis, the red pandora Pagellus bellottii and Sparus caeruleostictus. Others 
Table 3. Average values (SD) of the environmental variables for station Groups 1 to 9, January-February 1989

\begin{tabular}{|c|c|c|c|c|c|c|c|c|c|c|c|}
\hline \multirow{3}{*}{$\begin{array}{l}\text { Variables } \\
\text { No. of stations: }\end{array}$} & \multicolumn{11}{|c|}{ Group } \\
\hline & 1 & 2 & 3 & 4 & 5 & 6 & & 7 & 2 & 8 & 9 \\
\hline & 6 & 26 & 5 & 18 & 8 & 12 & & 7 & & 5 & 7 \\
\hline Depth (m) & 11 (1) & $21(10)$ & $39(9)$ & $40(14)$ & $79(18)$ & $93(22)$ & 219 & $(22)$ & 353 & (41) & $554(104)$ \\
\hline Temperature $\left({ }^{\circ} \mathrm{C}\right)$ & $28.1(0.1)$ & 27.1 (2.1) & $22.2(2.9)$ & $21.3(2.2)$ & $19.2(1.0)$ & $18.7(1.5)$ & 13.3 & $(0.6)$ & 10.3 & $(0.9)$ & $7.6(0.9)$ \\
\hline Salinity $(\%)$ & $32.0(0.0)$ & $33.3(1.1)$ & $35.2(0.8)$ & $35.3(0.6)$ & $35.8(0.1)$ & $35.8(0.3)$ & 35.3 & $(0.0)$ & 35.0 & $(0.1)$ & $34.7 \quad(0.0)$ \\
\hline Oxygen $\left(\mathrm{ml} \mathrm{l}^{-1}\right)$ & $4.8(0.0)$ & $4.6(0.3)$ & $4.0(0.4)$ & $4.1(0.4)$ & $2.9(0.3)$ & $3.2(0.4)$ & 1.8 & $(0.2)$ & 1.5 & $(0.0)$ & $1.9(0.3)$ \\
\hline
\end{tabular}

Table 4. Total weight ( $\mathrm{W}$, in $\mathrm{kg}$ ) and percent of all species, numbers $(\mathrm{N})$ and frequency ( $\mathrm{F}$ : no. of stations where found in the respective groups) of main species from station Groups 1 to 9 . Catch rate $=$ total W/F

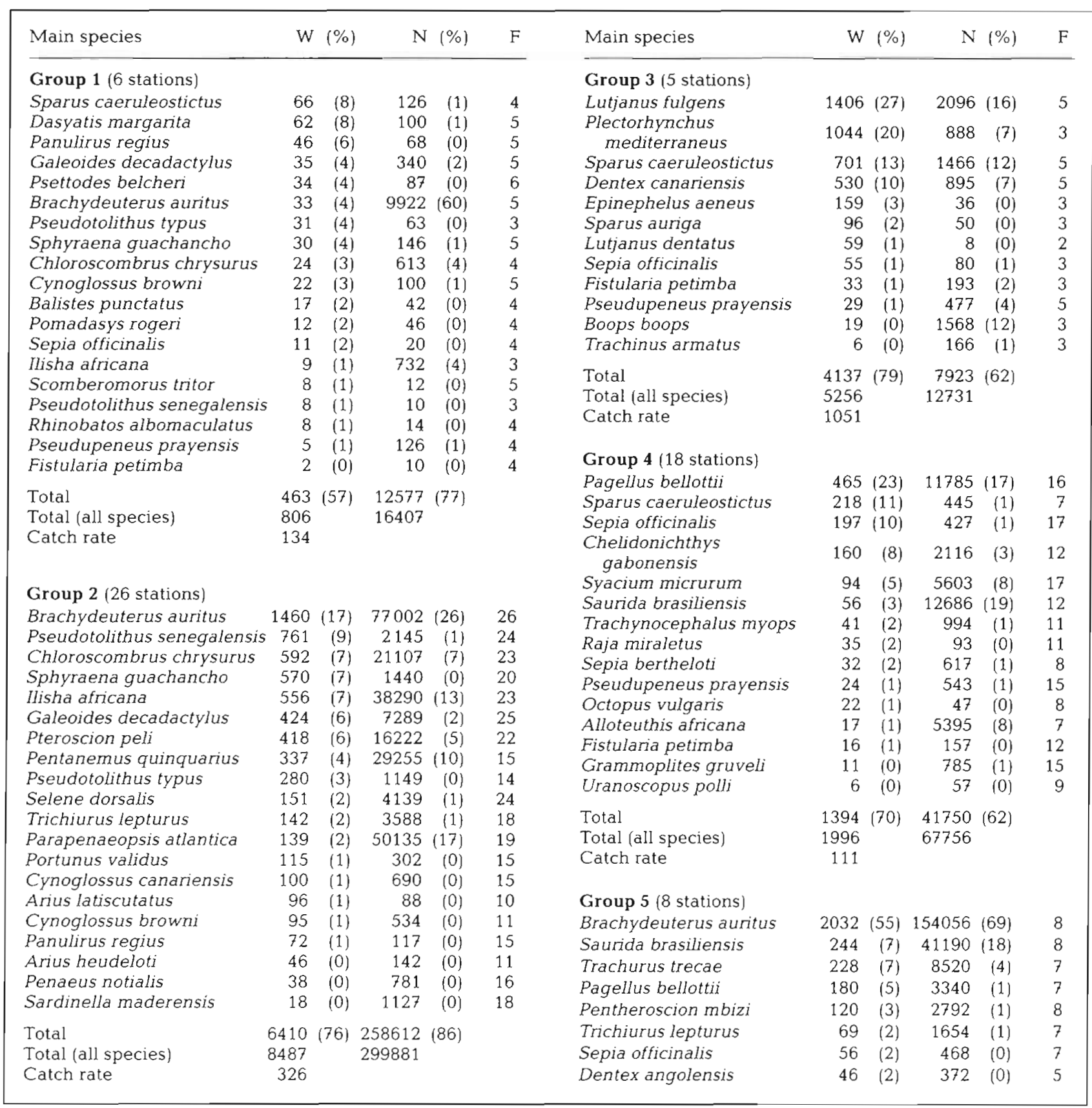


Table 4 (continued)

\begin{tabular}{|c|c|c|c|c|c|c|c|c|c|c|c|}
\hline Main species & W & $(\%)$ & $\mathrm{N}$ & $(\%)$ & F & Main species & W & $(\%)$ & & $(\%)$ & $\mathrm{F}$ \\
\hline Illex coindetii & 25 & (1) & 576 & $(0)$ & 5 & Bembrops heterurus & 36 & (2) & 1162 & (3) & 5 \\
\hline Citharus linguatula & 22 & (1) & 686 & (0) & 8 & Parapenaeus longirostris & 30 & (2) & 3609 & $(10)$ & 7 \\
\hline Lepidotrigla cadmâni & 21 & (1) & 226 & $(0)$ & 5 & Myctophidae & 21 & (1) & 6531 & (18) & 4 \\
\hline Brotula barbata & 12 & (0) & 38 & $(0)$ & 6 & Zenopsis conchifer & 20 & (1) & 54 & $(0)$ & 5 \\
\hline Parapenaeus longirostris & 7 & (0) & 868 & $(0)$ & 7 & Physiculus spp. & 4 & $(0)$ & 170 & $(0)$ & 4 \\
\hline Total & 3062 & (83) & 214786 & (96) & & Total & 1343 & $(67)$ & 26643 & (73) & \\
\hline Total (all species) & 3694 & & 222760 & & & Total (all species) & 2005 & & 36543 & & \\
\hline Catch rate & 462 & & & & & Catch rate & 286 & & & & \\
\hline \multicolumn{12}{|l|}{ Group 6 (12 stations) } \\
\hline Dentex congoensis & 1930 & $(32)$ & 68261 & $(30)$ & 11 & Group 8 (5 stations) & & & & & \\
\hline Trachurus trecae & 1651 & $(27)$ & 74948 & (33) & 10 & Nematocarcinus africanus & 551 & $(32)$ & 116976 & $(80)$ & 4 \\
\hline Boops boops & 585 & (10) & 24352 & (11) & 11 & Merluccius polli & 414 & $(24)$ & 2168 & (1) & 5 \\
\hline Pagellus bellottii & 517 & $(9)$ & 18628 & (8) & 12 & Centrophorus uyato & 164 & (9) & 67 & (0) & 4 \\
\hline Epinephelus aeneus & 115 & (2) & 30 & $(0)$ & 6 & Pterothrissus belloci & 156 & (9) & 1038 & (1) & 5 \\
\hline Lepidotrigla carolae & 110 & (2) & 3882 & (2) & 9 & Benthodesmus tenuis & 101 & (6) & 6038 & (4) & 5 \\
\hline Spicara alta & 102 & (2) & 9699 & (4) & 8 & Illex coindetii & 73 & (4) & 638 & $(0)$ & 5 \\
\hline Chelidonichthys & 83 & & & & & Physiculus spp. & 60 & (3) & 1206 & (1) & 5 \\
\hline gabonensis & 83 & (1) & 1505 & (1) & 12 & Neomerinthe folgori & 16 & (1) & 351 & (0) & 3 \\
\hline Lepidotrigla cadmani & 70 & (1) & 2374 & (1) & 7 & Coelorinchus coelorhincus & 5 & (0) & 189 & (0) & 4 \\
\hline Priacanthus arenatus & 54 & (1) & 638 & $(0)$ & 5 & Total & 1545 & (89) & 129334 & (89) & \\
\hline Dentex angolensis & 46 & (1) & 527 & (0) & 6 & Total (all species) & 1745 & & 145582 & & \\
\hline Saurida brasiliensis & 35 & (1) & 3550 & $(2)$ & 7 & Catch rate & 349 & & & & \\
\hline $\begin{array}{l}\text { Sepia bertheloti } \\
\text { Dentex canariensis }\end{array}$ & $\begin{array}{l}28 \\
21\end{array}$ & $\begin{array}{l}(0) \\
0\end{array}$ & $\begin{array}{r}613 \\
34\end{array}$ & $\begin{array}{l}(0) \\
(0)\end{array}$ & $\begin{array}{r}10 \\
4\end{array}$ & & & & & & \\
\hline Citharus linguatula & 19 & (0) & 958 & $\begin{array}{l}\text { (0) } \\
\text { (0) }\end{array}$ & 7 & Group 9 (7 stations) & & & & & \\
\hline Total & 5364 & (89) & 209997 & (91) & & Physiculus spp. & 145 & (13) & 1754 & (9) & 6 \\
\hline Total (all species) & 6045 & & 228928 & & & Malacocephalus occidentalis & $s 121$ & (11) & 1560 & (8) & 7 \\
\hline Catch rate & 504 & & & & & Merluccius polli & 107 & (10) & 305 & $(2)$ & 4 \\
\hline & & & & & & Coelorinchus coelorhincus & 97 & (9) & 1886 & $(10)$ & 7 \\
\hline Group 7 (7 stations) & & & & & & Polychaelidae & 59 & (5) & 3908 & $(20)$ & 7 \\
\hline Centrophorus uyato & 406 & $(20)$ & 54 & (0) & 2 & Illex coindeti & 59 & (5) & 444 & (2) & 6 \\
\hline Squatina oculata & 122 & (6) & 20 & (0) & 6 & Etmopterus spp. & 58 & (5) & 368 & (2) & 6 \\
\hline Pterothrissus belloci & 120 & (6) & 921 & (2) & 6 & Yarella blackfordi & 44 & (4) & 4242 & $(22)$ & 6 \\
\hline Illex coindeti & 119 & $(6)$ & 1447 & (4) & 7 & Aristeus antennatus & 14 & (1) & 349 & (2) & 6 \\
\hline Synagrops microlepis & 103 & (5) & 8726 & (24) & 4 & Aristeus varidens & 9 & (1) & 481 & (2) & 5 \\
\hline Pentheroscion mbizi & 94 & (5) & 770 & $(2)$ & 2 & Benthodesmus spp. & 9 & (1) & 468 & (2) & 4 \\
\hline Ariomma bondi & 92 & $(5)$ & 2296 & (6) & 1 & & & $(64)$ & 15765 & 811 & \\
\hline Brotula barbata & 83 & (4) & 145 & (0) & 4 & lotal & 1126 & (04) & 19430 & (01) & \\
\hline Etmopterus polli & 55 & (3) & 10 & (0) & 1 & $\begin{array}{l}\text { Total (all species) } \\
\text { Catch rate }\end{array}$ & $\begin{array}{r}1120 \\
162\end{array}$ & & 19430 & & \\
\hline Merluccius polli & 38 & $(2)$ & 730 & $(2)$ & 7 & Catch rate & 162 & & & & \\
\hline
\end{tabular}

were found in Group 4 but not in Group 3: the Guinea flathead Grammoplites gruveli, ray Raja miraletus, the bluntnose lizardfish Trachinocephalus myops, the octopus Octopus vulgaris, the Gabon gurnard Chelidonichthys gabonensis and the Brazilian lizardfish Saurida brasiliensis.

Both Groups 3 and 4 seem to correspond to the one described for the Gulf of Guinea by Fager \& Longhurst (1968) as an assemblage 'found at the bottom of the thermocline, mainly on hard bottoms, where the species that usually dominate the thermocline area are replaced by some members of the deeper sparid assemblage, probably because of the nature of the bottom'. The differences between the 2 groups appearing in Appendix 1 and Table 4 might be due to the presence, in some locations, of spawning aggregations where only a few species dominate.

\section{Subthermocline assemblages}

The following groups ( 5 and 6 ) include species of the subthermocline assemblages of the continental shelf (50 to 150-200 m). Two major groups were identified: an assemblage consisting, among others, of several species of Sparidae, with preference for sandy, fine sand to muddy bottoms and an assemblage including species with a clear preference for soft bottoms. The Cunene horse mackerel Trachurus trecae, Pagellus bellottii and Citharus linguatula were abundant in both groups.

Group 5 - subthermocline assemblage of soft bottoms, off Congo. Navigation charts (Anon. 1976) show the presence of mud, mud-sand bottom for the area where this type of assemblage is found. Its species composition confirms the presence of soft bottoms. 
A group of 8 stations, at an average depth of $79 \mathrm{~m}$, temperature of $19^{\circ} \mathrm{C}$, high salinity $(35.8 \%$ ) and oxygen levels of $2.9 \mathrm{ml} \mathrm{l}^{-1}$ were quite distinct in species association. Fifty-five percent of the catches consisted of Brachydeuterus auritus. An additional $30 \%$ consisted of Saurida brasiliensis, Trachurus trecae, Pagellus bellottii, Pentheroscion mbizi, Trichiurus lepturus, Sepia officinalis and Dentex angolensis. Brotula barbata and Parapenaeus longirostris were less abundant but quite common. This assemblage is almost identical in species composition to the one described for the muddy bottoms of northern Angola (Bianchi 1992). However, there the dominating species is the splitfin Synagrops microlepis (52\%), a species mainly of the upper slope. In fact that assemblage was described from a group of stations with a deeper depth range.

Group 6 - subthermocline sparid assemblage, off Gabon. This group includes 12 stations at an average depth of ca $93 \mathrm{~m}$, temperature of $18.7^{\circ} \mathrm{C}$, salinity $35.8 \%$, and oxygen concentration $3.2 \mathrm{ml} \mathrm{l}^{-1}$. The bottom is mainly sandy (Anon. 1976). Several seabream species (family Sparidae) dominate this assemblage that broadly coincides with Longhurst's (1965) 'subthermocline sparid subcommunity' of the Gulf of Guinea, also described for Congo by Durand (1967). Dentex congoensis and the bentho-pelagic Trachurus trecae dominated the catches both in biomass and numbers $(59 \%$ and $63 \%$, respectively; Table 4) and were present at almost all stations. Two additional species, Boops boops and Pagellus bellottii, accounted for an additional $20 \%$.

\section{Continental slope assemblages}

The slope stations range between 200 and $696 \mathrm{~m}$ depth. They have been divided into 3 groups following the TWINSPAN divisions. However, they seem to represent an almost perfect gradient, where species from shallower depths are gradually replaced by deeper water representatives (see Appendix 1).

Group 7 - upper edge of the continental slope. Seven stations are included in this group, at an average depth of $219 \mathrm{~m}$, temperature of $13.3^{\circ} \mathrm{C}$, salinity of $35.3 \%$ and oxygen levels of $1.8 \mathrm{ml} \mathrm{l}^{-1}$. There was no one dominant species. Squatina oculata is the indicator species while Centrophorus uyato accounts for $20 \%$ of the catches in biomass but has a low frequency (30\%). Pterothrissus belloci and Illex coindeti were the other 2 most abundant species. Synagrops microlepis, that made up $52 \%$ in biomass in the corresponding assemblage found off Angola, is definitely less abundant here $(5 \%)$

Group 8 - deeper continental slope $(300$ to $400 \mathrm{~m})$. Five stations were sampled, with the average depth of
$353 \mathrm{~m}$, temperature of $10.3^{\circ} \mathrm{C}$, salinity of $35.0 \%$ and oxygen levels of $1.5 \mathrm{ml}^{-1}$. Two species dominated the catches: the African spider shrimp Nematocarcinus africanus, the indicator species (32\% of the catches), and Merluccius polli (ca $24 \%$ ). In common with the shallower slope Group 7 are Pterothrissus belloci, lllex coindetii, Parapenaeus longirostris, Physiculus spp. and Benthodesmus tenuis. A species with a deeper range appearing in this group was the grenadier Coelorinchus coelorhincus.

Group 9 - deeper continental slope (400 to $700 \mathrm{~m})$. Eight stations were in this group, at an average depth of $554 \mathrm{~m}$, temperature of $7.6^{\circ} \mathrm{C}$, salinity of $34.7 \%$ and oxygen levels of $1.9 \mathrm{ml} \mathrm{l}^{-1}$. Bony fishes typical of this group are the grenadiers Coelorinchus coelorhincus, Malacocephalus occidentalis, and the bristlemouth Yarella blackfordi. Species of Physiculus and Merluccius polli, also found in the 2 other slope groups, contributed to $23 \%$ of the catches in biomass. Lantern sharks Etmopterus spp. represented the sharks in this depth range. A number of crustaceans also appeared as important elements of the fauna: lobsters of the family Polychaelidae, and the shrimps Aristeus antennatus and A. varidens.

The plot of mean biomass densities by depth stratum for Gabon and Congo is presented in Fig. 5 while Table 5 gives the number of stations sampled by depth stratum. Off Congo the maximum biomass on the shelf is given by the eurybathic species (mainly Brachydeuterus auritus) while the slope maximum occurs between 300 and $400 \mathrm{~m}$ and is mainly due to Nematocarcinus africanus and Merluccius polli. Off Gabon, an additional group was defined, consisting of eurythermic species with a preference for hard substratum (corresponding to Group 3 of the assemblage analysis). Its maximum is at 30 to $50 \mathrm{~m}$ while the eurybathic species found off Congo are very poorly represented. A maximum is found in the deeper part of the shelf, consisting of species of the 'sparid community' (Dentex congoensis, Trachurus trecae and Boops boops).

\section{DISCUSSION}

\section{Species assemblages}

The first TWIA division separates the shelf stations from the slope ones and thus constitutes the sharpest discontinuity. The faunal discontinuity is probably accentuated by the steepness of the shelf between ca 120 and $200 \mathrm{~m}$ and no station could be sampled in that depth range. DCA Axis 1 shows high correlation with temperature, oxygen and depth. These variables covary and it is difficult to interpret their effects separately. Temperature seems to be important in separat- 


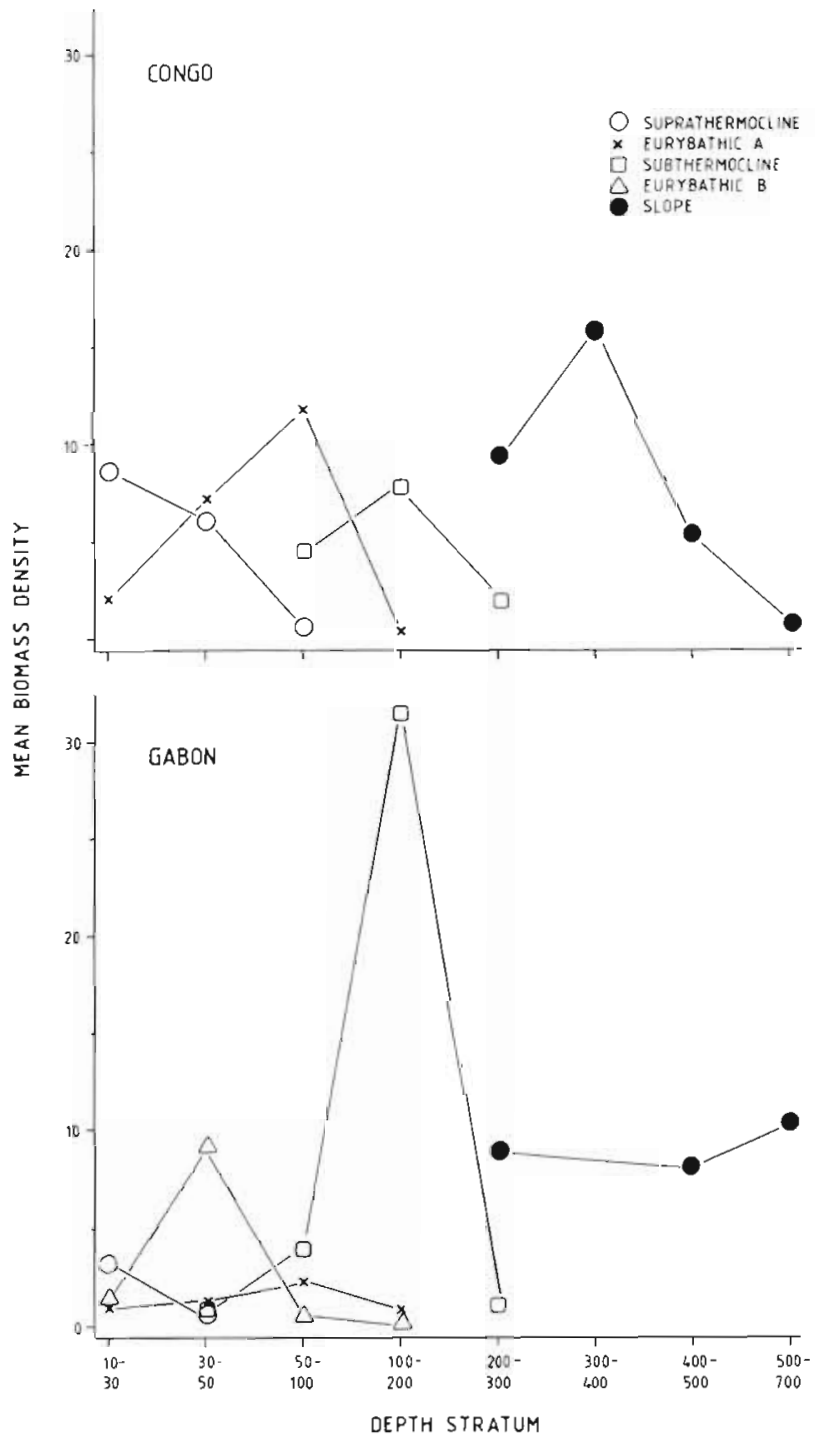

Fig. 5. Mean biomass density [t ( $\mathrm{n}$ mile $\left.)^{-2}\right]$ by depth stratum (m) from bottom trawl catches for Congo and Gabon, JanuaryFebruary 1989. For definition of species categories see 'Discussion - Biomass distribution'

ing the shallow water groups from the intermediate shelf ones. The thermocline seems to give rise to a distinct boundary and Groups 1 and 2, from shallow waters, have average temperatures 5 to $6{ }^{\circ} \mathrm{C}$ higher than Groups 3 and 4, just below the thermocline, while oxygen values are above $4 \mathrm{ml} \mathrm{l}^{-1}$ in the 4 groups (Table 3). From Appendix 1 it is also clear that most of the shallow water species are confined to Groups 1 and 2 , i.e. where waters have high temperature and oxygen values. The slope groups are also characterized by temperature values well below the values found on the shelf. Oxygen may play some role for the species in the deeper part of the shelf and on the slope. Depth, as already discussed in Bianchi (1991), is a spurious variable as it entails all other possible factors varying along the water column (temperature, oxygen, salinity, pressure, light intensity, etc.).

The importance of the presence of a sharp thermocline in the eastern Atlantic at shallow depths was already recognized by Longhurst (1965). Apart from clearly segregating shelf assemblages, the occurrence of cool subthermocline water at relatively shallow depths enables a number of cool sub-tropical fish to penetrate into the tropical region and explains how species of the family Sparidae, one of the most important demersal fishery resources, mostly represented in the Mediterranean, South Africa and the more temperate coasts of West Africa, can be so very abundant in the tropical area as well.

DCA Axis 2 did not show any significant correlation with the environmental variables used in this study. Groups 1 and 2 are separated along this axis, as well as Group 3 from Group 4, and Group 5 from Groups 4 and 6 (Fig. 3). This axis might reflect factors like differences in bottom type (i.e. Group 5 vs Group 6), spawning aggregations (Group 3) or presence of nursery areas (Group 1).

Fager \& Longhurst's (1968) description of the assemblages of the Gulf of Guinea derived from the data of the Guinean Trawling Survey largely coincides with the above groups. The 'sciaenid community' of estuarine areas and shallow waters corresponds to Group 2. Pseudotolithus senegalensis, P. typus, and Pteroscion peli are the dominating sciaenids and were chosen to represent this group because of their importance in fisheries. However, the eurybathic Brachydeuterus auritus dominate this group. The 'sparid community', characterized by a number of seabreams (family Sparidae) together with other families of sandy

Table 5. Number of stations used for swept-area estimates by depth stratum

\begin{tabular}{|c|c|c|c|c|c|c|c|c|}
\hline \multirow[t]{2}{*}{ Area } & \multicolumn{8}{|c|}{ Depth stratum (m) } \\
\hline & $10-30$ & $30-50$ & $50-100$ & $100-200^{\circ}$ & $200-300$ & $300-400$ & $400-500$ & $500-700$ \\
\hline Congo & 14 & 4 & 7 & 2 & 5 & 4 & 1 & 3 \\
\hline Gabon & 19 & 14 & 8 & 5 & 2 & 0 & 1 & 2 \\
\hline
\end{tabular}


deposits (Triglidae, Mullidae, Synodontidae and Platycephalidae) is also represented in the area under study, by its shallow component (Group 4, off Gabon) and deeper-shelf component (Group 6, also off Gabon). The latter represents the typical 'sparid community' where about $80 \%$ of the catches consist of Dentex congoensis (32\%), Trachurus trecae (27\%), Boops boops $(10 \%)$ and Pagellus bellottii $(9 \%)$. The intermediate shelf assemblage found off Congo seems to be rather different and this is possibly due to the muddy substratum found here. Although some elements of the 'sparid community' are found here (e.g. Dentex angolensis, Saurida brasiliensis, Trachurus trecae) other species with more affinity for muddy bottoms appear (Pentheroscion mbizi, Brotula barbata). Brachydeuterus auritus accounts for $55 \%$ of the catches here. However, its presence in this assemblage is only seasonal (Durand 1967). The values of the environmental variables are rather similar for the 2 groups (Table 3) and it seems evident that bottom type plays an important role in the faunal composition of these assemblages. Longhurst has not described this difference and included Pentheroscion mbizi in the typical 'sparid assemblage'.

Durand (1967) described the distribution, abundance and seasonal variations of the benthic fishes of the Congo continental shelf. It is interesting to compare the results from that study with the present one in order to find possible differences in the dominant species. He describes the shallow water assemblage as 'peuplement littoral' and this corresponds to Group 2 (this group includes mostly shallow waters off Congo). Pseudotolithus senegalensis, P. typus and Pteroscion peli made up $60 \%$ of the catches (possibly excluding the eurybathic species). In the shallow water group off Congo, the above species represent $18 \%$ in biomass of the catches (about $30 \%$ without the eurybathic species). Also, llisha africana, described as coming after the above species in Congo, seems now to be relatively more abundant and accounts for $7 \%$ of the catches from the assemblage.

As for the deeper shelf assemblage, Dentex angolensis was reported as the dominant species while it definitely did not appear as dominant in 1989. The shelf assemblage off Congo (Group 5; Table 4) shows that, at least in the warm season, Brachydeuterus auritus dominates (55\%) while $D$. angolensis accounts only for $2 \%$ of the catches.

The observed decline in the relative abundances of Pseudotolithus senegalensis, $P$. typus and Dentex angolensis might be due to high fishing pressure directed at these valuable groups.

As for the slope assemblages, no indication of zonation is given by Durand (1967) while we could identify at least 2 major groups ( 7 and $8-9$ ). The one described by Durand seems to correspond with Group 7 and some dominating species (Squatina oculata and Pterothrissus belloci) also dominated the catches of the upper slope assemblage represented by Group 7. Two large catches of Centrophorus uyato accounted for $20 \%$ of the catches in Group 7 while this species is not mentioned by Durand.

\section{Biomass distribution}

Because of the differences found in the assemblage structure of Congo and Gabon (South of Cape Lopez), these 2 sections were analyzed independently. The analysis was performed by grouping the species according to their ecological preferences. For Congo, the analysis was performed by dividing the species in 4 groups: shallow water, suprathermocline species; eurybathic species (Brachydeuterus auritus, Trichiurus lepturus, Sphyraena guachancho, Raja miraletus, Cynoglossus canariensis, Selene dorsalis and Cynoponticus ferox); deeper shelf species; and slope species.

It is interesting to note that, in correspondence with the thermocline area, the biomass of the shallow water and deeper shelf groups is at a minimum here, while the eurybathic species reach their maximum. Brachydeuterus auritus belongs to a typical demersal family (Haemulidae $=$ Pomadasyidae) but it is often observed off the bottom suggesting a semi-demersal type of behaviour. Its evolutionary success might be related to the instability of the thermocline area which would make this area uninhabitable for most species. As already observed by Durand (1967) the thermocline is subject to important seasonal fluctuations causing a minimum of demersal biomass. $B$, auritus seems to have developed as a eurythermic/eurybathic species capable of adjusting to environmental fluctuations. Also, its feeding habits suggest the capability of feeding both in intermediate waters as well as on the bottom. Although B. auritus is also found together with shallow water species as well as deeper ones, its maximum of occurrence is in areas where the other species, that form the target of various fisheries, do not occur so that this species is possibly not subject to the same fishing pressure.

An additional category was defined for Gabon (eurybathic B; Fig. 5), consisting of species found at similar depth ranges as the species of the eurybathic group mentioned above but with a preference for hard bottoms (species of Lutjanus, Dentex, Sparus, Pagellus and Epinephelus, but with a shallower depth distribution as compared with the respective congeneric species).

Fig. 5 shows how the above species groups are distributed according to depth. The maximum observed 
on the deeper shelf off Gabon (Fig. 5, lower graph) is quite remarkable. However, about $30 \%$ of this value is represented by a few high catches of Trachurus trecae. The remaining species are all typical demersal and alone they would still amount to a maximum value in this depth zone. The high fish densities observed off Congo between 300 and $400 \mathrm{~m}$ depth are largely due (about $70 \%$ ) to the spider shrimp Nematocarcinus africanus and the hake Merluccius polli.

The higher catches and fish densities observed in the deeper part of the shelf seem to deviate from the general conception that in tropical areas highest biomass densities are found in shallow, suprathermocline waters (Longhurst \& Pauly 1987). On the one hand, the definition 'tropical' should not be related to the latitudinal position of a given area but rather to the type of oceanographic regime found there. Thus Gabon and Congo, although definitely tropical in position, are subject to processes of enrichment (seasonal upwelling) that are probably responsible for the deviations in the distribution of demersal biomass described above. On the other hand, there is also a problem with the definition of 'demersal'. If 'demersal' is meant to cover only truly benthos-feeding animals, about $70 \%$ of the species of Table 1 should not be included in the analysis; the results might be different and may be consistent with the general view of decreasing demersal biomass with increasing depth. However, I have preferred to include all species consistently caught in the bottom trawl as their presence near the bottom might reflect some type of interaction with the benthic ecosystem. Studies on stomach contents are obviously needed to establish the possible trophic relationships.

Acknowledgements. I thank Gunnar Sætersdal and Tore Høisæter for reading the paper and providing valuable suggestions for its improvement, and Ståle Kolbeinson for drawing the figures.

\section{LITERATURE CITED}

Anonymous (1976). Cape Lopez to Luanda. Defence Mapping Agency Hydrographic Center, Washington, D.C.

Anonymous (1986). Report on surveys of Gabon marine fish resources, March-December 1985. Reports of surveys with $R / N$ 'Dr. Fridtjof Nansen'. Insitute of Marine Research, Bergen

Bianchi, G. (1986). Fìchas FAO de Identificação de espécies para propósitos comerciais. Guia de campo para as espécies comerciais marinhas e de aguas salobras de Angola. Preparado com o apoio da NORAD e da FAO (FIRM) Programa Regular. FAO, Rome

Bianchi, G. (1991). Demersal assemblages of the continental shelf and slope edge between the Gulf of Tehuantepec (Mexico) and the Gulf of Papagayo (Costa Rica). Mar. Ecol. Prog. Ser. 73: 121-140
Bianchi, G. (1992). Study on the demersal assemblages of the continental shelf and upper slope of Angola. Mar. Ecol. Prog. Ser. 81: 101-120

Cayré, P., Fontana, A. (1981). Les stocks démersaux profonds. In: Fontana, A. (ed.) Milieu marin et ressources halieutiques de la République populaire du Congo. Trav. Doc. ORSTOM 138: 153-211

Domain, F. (1972). Poissons démersaux du plateau continental sénégambien. Application de l'analyse en composantes principales à l'étude d'une série de chalutages. Cah. ORSTOM, sér. Océanogr. 10(2): 111-123

Domain, F. (1980). Contribution à la connaissance de l'écologie des poissons démersaux du plateau continentale sénégalo-mauritanien. Les ressources démersales dans le contexte général du Golfe de Guinée. Thèse de Doctorat d'Etat es - Sciences Naturelles. Université Pierre et Marie Curie, Paris

Durand, J.-R. (1967). Etude des poissons benthiques du plateau continental congolais. 3e partie: étude de la repartition, de l'abondance et des variations saisonnières. Cah. ORSTOM, sér. Océanogr. 5(2): 3-68

Fager, E. W., Longhurst, A. R. (1968). Recurrent group analysis of species assemblages of demersal fish in the Gulf of Guinea. J. Fish. Res. Bd Can. 25: 1405-1421

Fischer, W., Bianchi, G., Scott, W. B. (eds.) (1981). FAO species identification sheets for fishery purposes. Eastern central Atlantic; fishing areas 34,47 (in part). Vols. 1-7. Department of Fisheries and Oceans Canada, Ottawa, by arrangement with the Food and Agriculture Organization of the United Nations

Fontana, A. (1981). Les stocks demersaux côtiers. In: Fontana, A. (ed.) Milieu marin et ressources halieutiques de la Republique populaire du Congo. Trav. Doc. ORSTOM 138: $153-211$

Hill, M. O. (1979). TWINSPAN - a FORTRAN program for arranging multivariate data in an ordered two-way table by classification of individuals and attributes. Cornell University, Ithaca

Hill, M. O., Gauch, H. G. (1980). Detrended correspondence analysis, an improved ordination technique. Vegetatio 42: $47-58$

Jackson, D. A., Somers K. M. (1991). Putting things in order: the ups and downs of Detrended Correspondence Analysis. Am. Nat. 137(5): 704-712

Jongman, R. H. G., ter Braak, C. J. F., van Tongeren, O. F. R. (1987). Data analysis in community and landscape ecology. Pudoc, Wageningen

Lleonart, J., Roel, B. A. (1984). Análisis de las comunidades de peces y crustáceos demersales de la costa de Namibia (Atlántico Sudoriental). Invest. pesq. 48: 187-206

Longhurst, A. R. (1965). A survey of the fish resources of the eastern Gulf of Guinea. J. Cons. int. Explor. Mer 29(3): 300-334

Longhurst, A. R., Pauly, D. (1987). Ecology of tropical oceans. Academic Press, New York

Mas-Riera, J., Lombarte, A., Gordoa, A., Macpherson, E. (1990). Influence of the Benguela upwelling on the structure of the demersal fish populations off Namibia. Mar. Biol. 104: 175-182

Roel, B. A. (1987). Demersal communities off the west coast of South Africa. In: Payne, A. I. L., Gulland, J. A., Brink, K. H. (eds.) The Benguela and comparable ecosystems. S. Afr. J. mar. Sci. 5: 575-584

Sxtersdal, G. (1989). Surveys of the fish resources of Congo and Gabon. Preliminary report Cruise N 1 (25 January8 February 1989). Report of surveys with R/V 'Dr. Fridtjof Nansen'. Institute of Marine Research, Bergen 
ter Braak, C. J F. (1987). CANOCO - a FORTRAN program for canonical community ordination by (partial) (detrended)(canonical) correspondence analysis, principal component analysis and redundancy analysis (Version 2.1). ITI-TNO, Wageningen

Voituriez, B., Herbland, H. (1982). Comparaison des systèmes

This article was submitted to the editor productifs de l'Atlantique tropical est: domes thermiques, upwellings côtiers et upwelling équatorial. Rapp. P.-v. Réun. Cons. int. Explor. Mer 180: 114-130

Wauthy, B. (1983). Introduction à la climatologie du Golf de Guinée. Océanogr. Trop. 18(2): 103-138

Manuscript first received: March 3, 1992

Revised version accepted: June 22, 1992 
Appendix 1. Two-way station by species table resulting from the program TWINSPAN. Values denote categories of abundance: (1) $W<0.5 \mathrm{~kg}$; (2) $0.5<W \leq 5 \mathrm{~kg}$; (3) $5<W \leq 50 \mathrm{~kg}$; (4) $50<W \leq 500 \mathrm{~kg}$; (5) $W>500 \mathrm{~kg}$. The dendrogram showing the hierarchical relationship between the various groups was substituted for the binary notation produced by the program

Mustelus mustelus Trichurus lepturus Cynoglussus canar. Sardinella maderen Galeoides decadact. Pseudotolithus typ. Dicologoglossa cun Chloroscombrus chr. Arius latiscutatus Sardinella aurita Ilisha africana Pseudotolithus sen. Parapenaeopsis atl. Arius heudeloti Pomadasys jubelini Portlunus validus Pteroscion peli Pentanemus quinqua Cynoglossus browni Sphyraena guachano. Eucinostomus melan. Panulirus regius Dasyatis margarita Scomberomorus trit Brachydeuterus aur. Penaeus notialis Pomadasys rogeri Rhinobatos albomac. Psettodes belcheri Balistes punctatus Grammoplites gruv. Uranoscopus polli Raja miraletus

Pseudupeneus pray. Syacium micrurum Fistularia petimba Trachynocephalus $m$ Trachinus armatus Sparus caeruleosti. Acanthurus monro Lutjanus fulgens Sparus auriga Plectorhynchus med. Octopus vulgaris Sepia officinalis Alloteuthis afric. Pagellus bellotii Chelidonichthys ga. Epinephelus aeneus Saurida brasilien Trachurus trecae Spicara alta

Priacanthus arenat Boops boops

Citharus linguatula Dentex congoensis Lepidotrigla car. Sepia bertheloti Dentex canariensis Torpedo torpedo Ariomma bondj Lepidotrigla cadm. Dentex angolensis Pentheroscion mbi. Brotula barbata Squatina oculata Parapenaeus longir Pterothrissus bel. Zenopsis conchifer llex coindetii

Centrophorus uyato Merluccius polll Physiculus spp. Neomerinthe folgori Benthodesmus spp. Polychaelidae Coelorinchus coel. Malacocephalus occ. Etmopterus spp. Aristeus varidens Nematocarcinus afr. Aristeus antennatus Yarella blackfordi

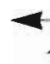

1

2 Shelf

$--32-32-32-3223--3-2333232-3223-$ $-3-31-2-3223-2-122333$ $322-33 \quad 3333434432233233333413323$ $22-3-333-33-24433--33-\cdots-22$ 1 - - 3$-22-33-3-33332333334443332233-23$ $-22-2--33-23---33-3-22--$
$-2-2221223333-232333232133-12$ $-2-23-32233-4333334343323-32222$ $-2-33243433332344333333-3-33334$ - $-233323-333121223-3123--$ $-33---2223-23--22-222-$ $\begin{array}{cc}---3- & -3-3--2322-22--\cdots \\ -\cdots-2 & 333---2233--23--22--2332 \ldots-\end{array}$ $-2--2 \quad 233-32-223433333221--33343$ -- - - -333-- 3-344322433---33--

$322-33-3-331-3--332----222-\cdots$ $323-32 \quad 33-24323433333333332 \cdots 2$ $22--2-1----322----1+--3122-$ $332-22--32-1-321233223----22-2$ $123-33-24332-3-2-----3-$ $\begin{array}{ll}2222-2 & -2--22222----2-\cdots \\ 222-33 & 43433243442344333342333444\end{array}$ $1----232---1-2-2222--22-22232$ $222--2-2-23----2-222---23-----1--$

$-2223---3-1-2---2-\cdots$
$223333---1-$
$222-3-$

$222-3-22323$ $21-2-12-1$ $21-22-2-2-2-2-2-22231$ $21-22$
$21--2-1-11-21-1-22221 \ldots$
$11--22$ $311-22-1 \ldots$ $323-3-\cdots$ $323-3-3-\ldots 1-\ldots$ $22-2-2--22-3-\cdots$
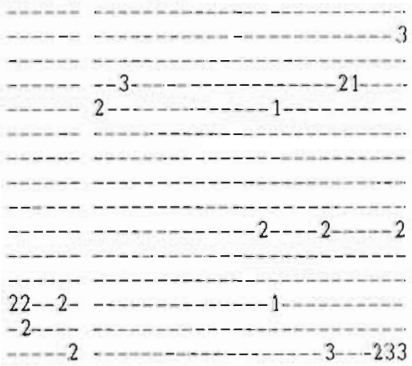

$$
3
$$

$$
4
$$
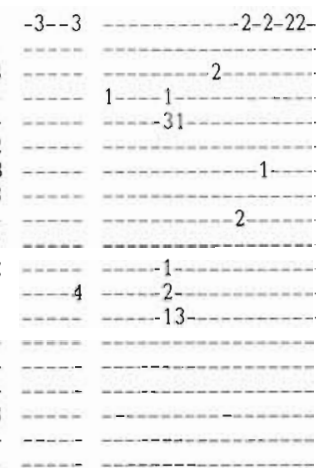

5

6

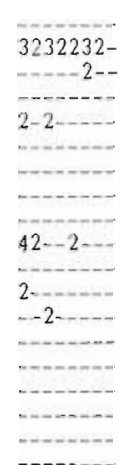

$3333-3-$

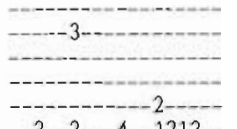

$$
--2--2--4--1212--
$$$$
\text { 212--11-2-1--1--- }
$$$$
23-2-32-\cdots
$$$$
23-23-2-2-2
$$$$
\begin{array}{ll}
3-2 & 22122212211-1-2-1 \\
-\cdots-2 & -2-12-111-1--12-\cdots
\end{array}
$$$$
\text { - } 332--3-3-222-2222-
$$

12322 222-1311211122-13-

$\begin{array}{ll}---13 & 33322232222222-122 \\ 23-2- & ---222-1211222-22-\end{array}$

$\begin{array}{ll}---2 & 2323-3333--1=-1-1- \\ -2-12 & 22133--13----2-\cdots\end{array}$

33444 4----3--34--2--24-

4-43-

32544

$1-4-3$
--553

\section{$--12--1-322-2-2--$}

$-333-34233333233323232-$

$\begin{array}{lll}-2-33 & -1-2-\cdots 3334233-2313343- & 32333-33\end{array}$

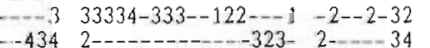

$\begin{array}{rrr}-434 & 2-----0-323- & 2-34 \\ --- & 123---2--322-21211 & 22343244\end{array}$

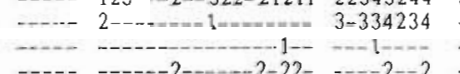

$--323$

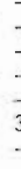

$-323-$

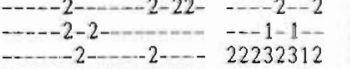
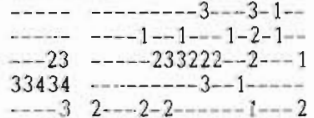

22232312

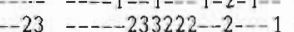

33434

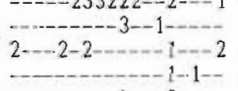

$-3-2-\cdots$

$-22--3$

$-3322$

$-33--4$
--32322
--33333

-33333
--32333322

32333322
$2--22222$

2--22222

21-22211

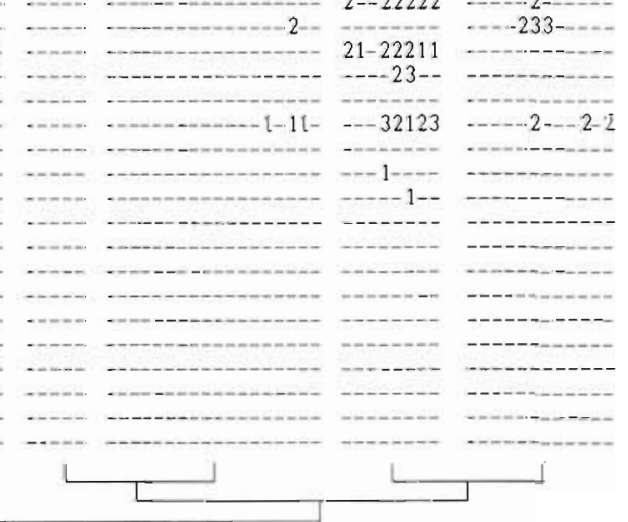

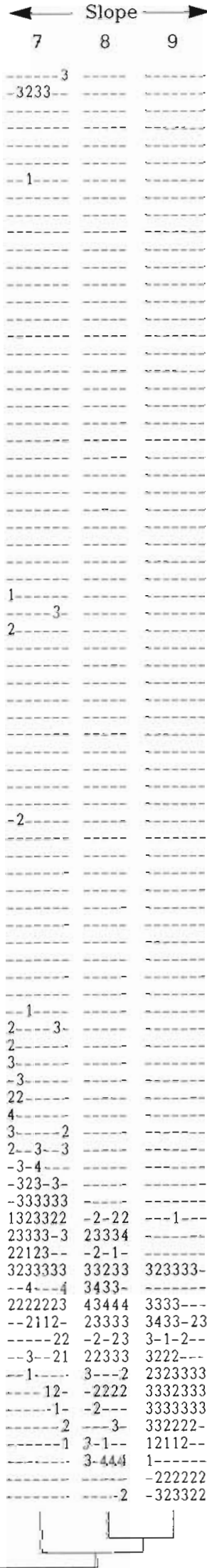

